\title{
Fate of Propanil in Soils
}

1. The Formation of 3,4-Dichloroacetanilide (DCAA)

\section{Masatsune ODA and Mineko YuKimoto}

Agricultural Chemicals Inspection Station, Ministry of

Agriculture and Forestry, Kodaira, Tokyo

\section{Summary}

3,4-Dichloroacetanilide (DCAA) was isolated from soils to which propanil or 3,4-dichloroaniline (DCA) was applied. Its identity was established by comparison with authentic DCAA using mass and infrared spectroscopys and gaschromatography.

Time cource of the accumulation of DCAA showed various patterns with the soils such as sand, Arakida soil, field soil and compost. Conversion of DCAA from either propanil or DCA was observed in three types of the soils except for sand, and the quantity of the accumulation was greatest in the compost. About $1.8 \%$ of applied propanil and $3.6 \%$ of DCA were converted to DCAA in the compost. The amount of DCAA accumulated in the soil increased when carbaryl was added to the applied DCA showing about $7 \%$ conversion of DCA. DCAA was rapidly decreased to a negligible amount in a month.

There was an optimum amount of applied DCA for the accumulation of DCAA in the soil. The conversion of DCAA from DCA was not observed in the soil sterilized by an autoclave. DCAA was produced in a DCA containing culture of soil microorganisms, and the production of DCAA was inhibited by sonication or addition of $\mathrm{Hg}^{++}$. These results demonstrate that the conversion of DCAA from propanil or DCA depends on the soil microorganisms.

\section{宮城県における 水田雑草の分 布}

\author{
宮城県古川農業試験場＼cjkstart高橋周寿・鈴木贸蔵*・武田昭七・菊池忠継 \\ クミアイ化学工業株式会社 佐 藤 憲 武
}

\section{は しがき}

宮城県で除草剤による雑草防除が実際に行われるよう になったのは昭和 26 年からであり, それ以前の除草法 ${ }^{1)}$ をみると, 明治 30 年代はもっぱら手取除草, 明治 40 年 代から大正初期は雁爪十手取除草であった。その後, 正 条植えの奖励と並行して八反取りなどの人力除草機が使 用され，昭和に入ってからは中耕を来祖た回転展土型除 草機 2 回十手取除草 2 回十七エ拔きが標淮除草法として 広く普及した。この炎天下の重兴働であった水田除草作
業が，除草剤利用による除草法に変わったことは，進歩 著しい稲作技術の中でも画期的な技術革新といわれてき た。しかも機械移植栽培の普及に伴い，除草剤に対する 依存度はますます高くなりつつある。

しかし, 最近全国的にホタルイなどの多年生雑草の優 占化が問題となり, その防除技術の確立が焦眉の課題と なっている。宮城県においても同様で，ホタルイを含む 多年生雑草の增加は著しいものがある。

以上のことから，筆者らは，水田主要雑草の県内地域 別の発生状況を明らかにし，防除技術確立の資に供する

* 現在, クミアイ化学工業株式会社 
ため, アンケート調查を行ったので，その結果の概要索 報告する。

調查結果の取りまとめに当たり, 助言と校閲を賜った 宮城県古川農業試験場長宫本硬一博士，調査に協力をい ただいた県内各農業改良普及所ならびに農家の方々に深 甚の謝意を表する。

\section{1. 県内稲作地域区分とその特徵}

稲作地域区分と農業改良普及所の管轄区域は第 1 図の とおりで，各地域の概況は以下のとおりである。

I：山間高冷地域（県内水田面積の $2 \%$ ）中央山脈 沿いの標高 $200 \mathrm{~m}$ 以上の地帯で, 火山灰士の泠水掛りの 漏水田が多い。

II : 内陸地域 $(83 \%)$ さらに 3 地区に分けられる。

II a : 内陸中北部 (54\%) 山麓抢よび平坦地帯で, 河川沖積の埴土ないし埴壌土の水田が多い。

II b : 内陸低湿部 (20\%) 河川下流の沖積呧湿地带 で，泥炭田や過腐植水田が多い。

II c : 内陸南部 ( $9 \%$ ) 平坦地滯で，河川流域の沖 積埴土ないし埴壤土の水田が多い。

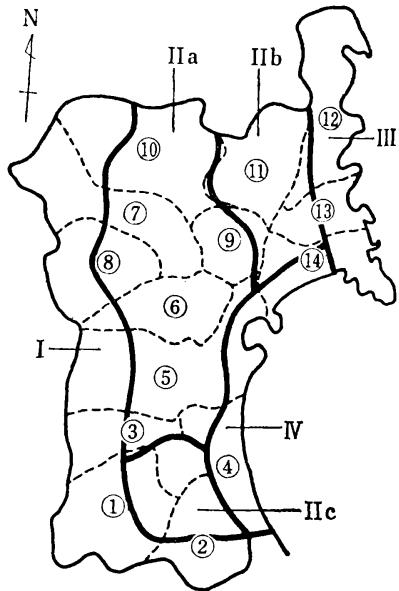

第 1 図 宮城県の稻作地域区分と農業 改良普及所別管轄区域

注） I IV : 地域区分, (1) (14)：管轄区域

III : 三陸沿崖地域（ $3 \% ）$ 海流の影響を強く受ける 地带で，沖積掞よび海成沖積の砂に富む砂質の水田が多 く, 漏水田や塩害田が分布している。

IV : 仙台湾沿岸地域 $(12 \%)$ 大部分が海成沖積, 海

第 1 表 地域別の雑草の発生状況ならびに残存状況 (1974)

\begin{tabular}{|c|c|c|c|c|c|c|c|c|c|c|c|c|}
\hline 普及所名 雑草名 & 'ピ $x$ & ホタルイ & $\begin{array}{l}\text { ミズガヤ } \\
\text { ツリ }\end{array}$ & $\begin{array}{l}ク \text { クログワ } \\
1\end{array}$ & マツパイ & オモダ力 & $=ナ \neq$ & ウリカワ & $\begin{array}{l}1 \text { 年生 } \\
\text { カカツ篎 }\end{array}$ & ヒルルン & \begin{tabular}{|l} 
ヘラオオモ \\
ダガ
\end{tabular} & オオフブ \\
\hline 1 白 石 $\left\{\begin{array}{l}a \\
b\end{array}\right.$ & $\begin{array}{l}50 \\
(17)\end{array}$ & $\begin{array}{c}25 \\
(33)\end{array}$ & $\begin{array}{c}50 \\
(100)\end{array}$ & $\begin{array}{c}42 \\
(60)\end{array}$ & $(\stackrel{33}{-})$ & $\begin{array}{c}42 \\
(60)\end{array}$ & $\stackrel{8}{-}$ & $\begin{array}{c}8 \\
(100)\end{array}$ & $(\stackrel{42}{-})$ & $\begin{array}{l}25 \\
(67)\end{array}$ & $(\stackrel{0}{-})$ & $\stackrel{0}{(-)}$ \\
\hline 2 角 田 $\left\{\begin{array}{l}\mathrm{a} \\
\mathrm{b}\end{array}\right.$ & $\begin{array}{c}40 \\
(13)\end{array}$ & $\begin{array}{c}25 \\
(80)\end{array}$ & $\begin{array}{c}60 \\
(100)\end{array}$ & $\begin{array}{c}45 \\
(100)\end{array}$ & $\begin{array}{c}35 \\
(43)\end{array}$ & $\begin{array}{c}35 \\
(57)\end{array}$ & $\stackrel{20}{-}$ & $\begin{array}{c}20 \\
(100)\end{array}$ & $\left(\begin{array}{c}0 \\
-\end{array}\right.$ & $\stackrel{0}{(-)}$ & $\begin{array}{c}5 \\
(100)\end{array}$ & $(\stackrel{0}{-})$ \\
\hline 3 大河原 $\left\{\begin{array}{l}a \\
b\end{array}\right.$ & $\begin{array}{l}57 \\
(50)\end{array}$ & $\begin{array}{c}29 \\
(100)\end{array}$ & $\begin{array}{c}57 \\
(100)\end{array}$ & $\begin{array}{c}29 \\
(100)\end{array}$ & $(\stackrel{29}{-)}$ & $(\stackrel{0}{-})$ & $\stackrel{29}{-}$ & $(\stackrel{0}{-})$ & $\stackrel{0}{(-)}$ & $\stackrel{0}{-}$ & $\stackrel{0}{-}$ & $\left(\begin{array}{c}0 \\
-)\end{array}\right.$ \\
\hline 4 亘 理 $\left\{\begin{array}{l}a \\
b\end{array}\right.$ & $\begin{array}{l}78 \\
(14)\end{array}$ & $\begin{array}{c}11 \\
(100)\end{array}$ & $\begin{array}{c}33 \\
(100)\end{array}$ & $\begin{array}{c}56 \\
(100)\end{array}$ & $\begin{array}{c}44 \\
(25)\end{array}$ & $(-22)$ & $\stackrel{33}{-})$ & $\begin{array}{c}67 \\
(100)\end{array}$ & $\stackrel{22}{(-)}$ & $\begin{array}{l}22 \\
(50)\end{array}$ & $\stackrel{0}{-}$ & $\begin{array}{c}22 \\
(50)\end{array}$ \\
\hline 5 仙 台 $\left\{\begin{array}{l}a \\
b\end{array}\right.$ & $(-)$ & $\begin{array}{c}62 \\
(75)\end{array}$ & $\begin{array}{c}69 \\
(100)\end{array}$ & $\begin{array}{c}39 \\
(100)\end{array}$ & $(\stackrel{39}{-)}$ & $(\stackrel{15}{-)}$ & $(\stackrel{23}{-})$ & $(\stackrel{0}{-})$ & $\stackrel{23}{-}$ & $\begin{array}{l}15 \\
(50)\end{array}$ & $\stackrel{0}{-})$ & $\begin{array}{c}23 \\
(100)\end{array}$ \\
\hline 6 大 和 $\left\{\begin{array}{l}a \\
b\end{array}\right.$ & $(20)$ & $\begin{array}{l}100 \\
(100)\end{array}$ & $\begin{array}{c}20 \\
(100)\end{array}$ & $(\stackrel{0}{-})$ & $(-60)$ & $\begin{array}{c}20 \\
(100)\end{array}$ & $(\stackrel{80}{-})$ & $\begin{array}{c}20 \\
(100)\end{array}$ & $\stackrel{20}{(-)}$ & $\stackrel{0}{-}$ & $(\stackrel{0}{-})$ & $(\stackrel{0}{-}$ \\
\hline 7 古 川\{ $\begin{array}{l}\mathrm{a} \\
\mathrm{b}\end{array}$ & $\begin{array}{l}42 \\
(13)\end{array}$ & $\begin{array}{l}68 \\
(85)\end{array}$ & $\begin{array}{c}21 \\
(100)\end{array}$ & $\begin{array}{c}32 \\
(100)\end{array}$ & $(21)$ & $\begin{array}{c}26 \\
(20)\end{array}$ & $\stackrel{26}{-})$ & $\begin{array}{l}37 \\
(71)\end{array}$ & $\stackrel{5}{(-)}$ & $\begin{array}{l}37 \\
(71)\end{array}$ & $\begin{array}{c}26 \\
(100)\end{array}$ & $\stackrel{5}{(-)}$ \\
\hline 8 中新田 $\left\{\begin{array}{l}\mathrm{a} \\
\mathrm{b}\end{array}\right.$ & $\begin{array}{c}75 \\
(50)\end{array}$ & $\begin{array}{c}50 \\
(75)\end{array}$ & $\begin{array}{c}50 \\
(100)\end{array}$ & $\stackrel{0}{(-)}$ & $\begin{array}{c}25 \\
(50)\end{array}$ & $\begin{array}{c}50 \\
(50)\end{array}$ & $(-13$ & $\begin{array}{c}38 \\
(100)\end{array}$ & $\stackrel{0}{(-)}$ & $\begin{array}{c}63 \\
(40)\end{array}$ & $\stackrel{0}{(-)}$ & $\stackrel{0}{-})$ \\
\hline 9 小牛田 $\left\{\begin{array}{l}a \\
b\end{array}\right.$ & $\begin{array}{c}46 \\
(20)\end{array}$ & $\begin{array}{c}37 \\
(25)\end{array}$ & $\begin{array}{c}27 \\
(100)\end{array}$ & $\begin{array}{c}55 \\
(100)\end{array}$ & $\begin{array}{c}46 \\
(40)\end{array}$ & $\begin{array}{c}27 \\
(67)\end{array}$ & $\stackrel{9}{-})$ & $\begin{array}{c}37 \\
(100)\end{array}$ & $(\stackrel{27}{-})$ & $\left(\begin{array}{c}0 \\
(-)\end{array}\right.$ & $\begin{array}{c}9 \\
(100)\end{array}$ & $\stackrel{0}{-})$ \\
\hline 10 筑 館 $\left\{\begin{array}{l}a \\
b\end{array}\right.$ & $\stackrel{83}{-})$ & $\begin{array}{c}33 \\
(67)\end{array}$ & $\begin{array}{c}33 \\
(100)\end{array}$ & $\begin{array}{c}83 \\
(100)\end{array}$ & $\begin{array}{c}33 \\
(50)\end{array}$ & $(\stackrel{16}{-)}$ & $\stackrel{50}{-}$ & $\begin{array}{c}16 \\
(100)\end{array}$ & $\stackrel{50}{-})$ & $(\stackrel{16}{-)}$ & $\stackrel{0}{(-)}$ & $\stackrel{0}{-}$ \\
\hline 11 迫 $\left\{\begin{array}{l}\mathrm{a} \\
\mathrm{b}\end{array}\right.$ & $\begin{array}{c}86 \\
(33)\end{array}$ & $\begin{array}{c}14 \\
(100)\end{array}$ & $\begin{array}{c}14 \\
(100)\end{array}$ & $\begin{array}{c}43 \\
(100)\end{array}$ & $\begin{array}{l}43 \\
(50)\end{array}$ & $\begin{array}{l}43 \\
(33)\end{array}$ & $\stackrel{43}{-})$ & $\stackrel{0}{-}$ & $\stackrel{0}{(-)}$ & $\begin{array}{c}29 \\
(50)\end{array}$ & $\stackrel{0}{-})$ & $\stackrel{0}{-}$ \\
\hline 12 本吉 $\left\{\begin{array}{l}a \\
b\end{array}\right.$ & $(-78)$ & $\begin{array}{c}67 \\
(100)\end{array}$ & $\begin{array}{c}11 \\
(100)\end{array}$ & $\begin{array}{c}11 \\
(100)\end{array}$ & $(\stackrel{0}{-})$ & $\begin{array}{c}22 \\
(100)\end{array}$ & $\begin{array}{c}22 \\
(50)\end{array}$ & $\stackrel{0}{(-)}$ & $(\stackrel{22}{-})$ & $\begin{array}{c}11 \\
(100)\end{array}$ & $\stackrel{0}{-})$ & $\stackrel{0}{-}$ \\
\hline 13 河 北 $\left\{\begin{array}{l}\mathrm{a} \\
\mathrm{b}\end{array}\right.$ & $\begin{array}{c}88 \\
(29)\end{array}$ & $\begin{array}{c}50 \\
(100)\end{array}$ & $\begin{array}{c}25 \\
(100)\end{array}$ & $\begin{array}{c}13 \\
(100)\end{array}$ & $\begin{array}{c}38 \\
(33)\end{array}$ & $\begin{array}{c}38 \\
(67)\end{array}$ & $\stackrel{38}{-})$ & $\begin{array}{c}13 \\
(100)\end{array}$ & $(\stackrel{38}{-)}$ & $\stackrel{0}{-}$ & $\begin{array}{c}13 \\
(100)\end{array}$ & $\stackrel{0}{-}$ \\
\hline 14 石 巻 $\left\{\begin{array}{l}\mathrm{a} \\
\mathrm{b}\end{array}\right.$ & $\begin{array}{c}43 \\
(33)\end{array}$ & $\begin{array}{l}57 \\
(75)\end{array}$ & $\begin{array}{c}21 \\
(100)\end{array}$ & $\begin{array}{c}36 \\
(100)\end{array}$ & $\begin{array}{c}36 \\
(40)\end{array}$ & $\begin{array}{c}29 \\
(50)\end{array}$ & $\begin{array}{c}29 \\
(25)\end{array}$ & $\begin{array}{c}7 \\
(100)\end{array}$ & $\stackrel{21}{-})$ & $\stackrel{0}{-}$ & $\begin{array}{c}29 \\
(75)\end{array}$ & $\begin{array}{c}14 \\
(50)\end{array}$ \\
\hline 県平均 $\left\{\begin{array}{l}\mathrm{a} \\
\mathrm{b}\end{array}\right.$ & $\begin{array}{c}56 \\
(19)\end{array}$ & $\begin{array}{l}45 \\
(87)\end{array}$ & $\begin{array}{c}37 \\
(100)\end{array}$ & $\begin{array}{l}37 \\
(94)\end{array}$ & $\begin{array}{c}33 \\
(25)\end{array}$ & $\begin{array}{c}28 \\
(48)\end{array}$ & $\begin{array}{l}26 \\
(5)\end{array}$ & $\begin{array}{l}20 \\
(93)\end{array}$ & $\stackrel{18}{-})$ & $\begin{array}{l}16 \\
(57)\end{array}$ & $\begin{array}{c}8 \\
(92)\end{array}$ & $\begin{array}{c}5 \\
(63)\end{array}$ \\
\hline 残存の程度の順位 & 10 & 5 & 1 & 2 & 9 & 8 & 11 & 3 & 12 & 7 & 4 & 6 \\
\hline
\end{tabular}

注） $\mathrm{a}$ : 主要雑草としての常在度 $(\%)$; 主要雑草とした農家数/全回签農家数

b : 残存の程度 $(\%)$; 除草郕使用後の残存雑草とした農家数/主要雑草とした濃家数 
岸沿沖積などの低湿地である。

\section{2. 調 查 方 法}

調查時期：1974 年 8 月。調查方法：次の上うな内容 の往復はがきを 1 普及所あて 20 枚配布し, 普及所が選 んだ農家から直接返送を受けた。

除草剤の効果出よび雑草調查について（アンケート）

- 栽境法科荘, 中藏, 成苗

- 水もち 1.2 . 3.4 月以.

・代かき ת 日

- 曰植え（機械移植, 手植え, 月 П) - 除草法

\begin{tabular}{c|cc|cc}
\hline 除草 剂 & 名 & 処 理 時期 & 薬 & 量 \\
\hline & 月 & 日 & & $\mathrm{kg} / 10 \mathrm{a}$ \\
\hline & 月 & 日 & & $\mathrm{kg} / 10 \mathrm{a}$
\end{tabular}

\begin{tabular}{l|ll|l}
\hline & 月 & 日 & $\mathrm{kg} / 10 \mathrm{a}$ \\
\hline & 月 & 日 & $\mathrm{kg} / 10 \mathrm{a}$ \\
\hline
\end{tabular}

- 貴家のほ場に発生する主な雑草名

・ 今年除草剂を使用して残った雑草名

・雑草が残った場合のとられた対策

（そのまま，手取り，機械中耕）

・使用した薬剂に刘する意㒫

$$
\text { 住所 }
$$

氏名

回答率扩よび栽培法：配付数 280 , 回答率 $84.5 \%$, 回 答者の栽培法は機械移植が $85.8 \%$, 成苗手植え $14.2 \%$ であった。

\section{3. 結果と考察}

\section{（1）地域別雑草発生状況之残存状況}

ある雑草を主要な雑草として記載した農家数の全回答

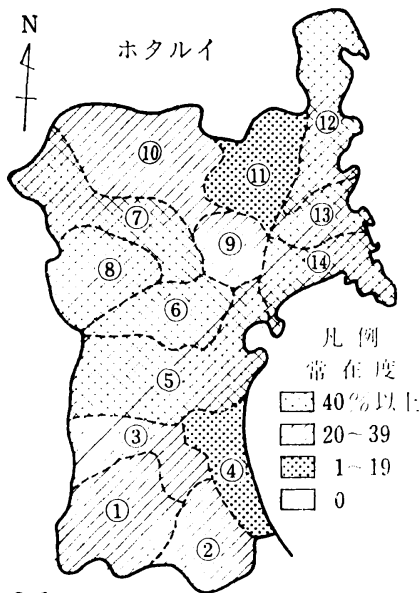

2-1

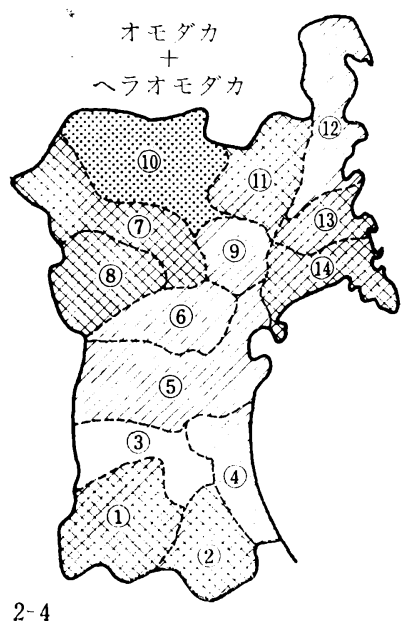

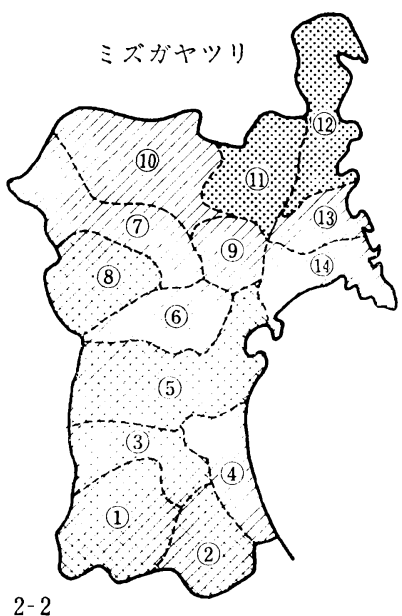

2-2

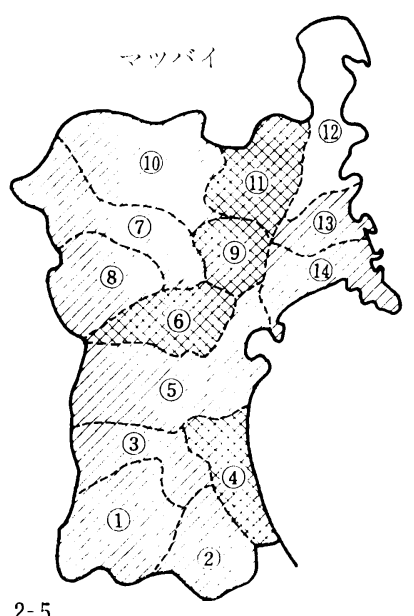

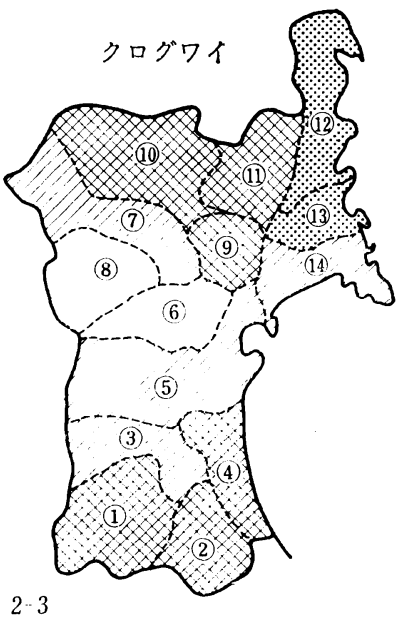

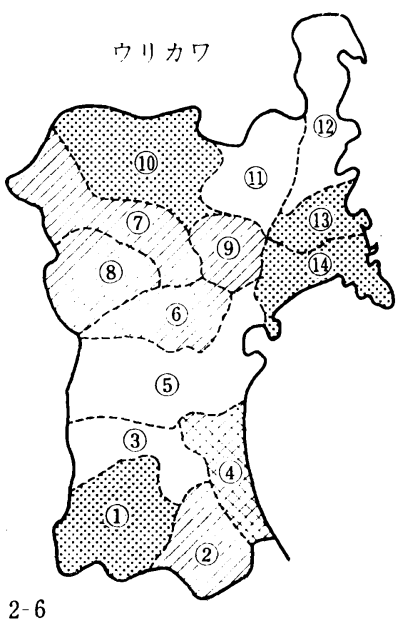

第 2 図地域別の主要雑草の筑生状況（第 1 表から作図） 
農家数に対する百分率を，本報では 主要雑草の常在度と表現することに した。この数值が高いほど, その雑 草の主要雑草としての分布が広いこ とを意味しているが，除草剤使用前 の主な雑草の地域別発生状況は第 1 表のとおりで, 主な雑草の常在度は ノビエが最も高く, ついでホタル イ, ミズガヤツリ, クログワイ, マ ツバイ, オモダカ, コナギ, ウリカ ワの順であり, 昭和 41 年調査によ る県内優占雑草の順位が, 地域点問 わずノビエ, マツバイ, コナギであ ったことと ${ }^{2)}$ 比較して，明らかに変 わったといえる。除草剤使用後の残 存の程度は, ミズガヤツリ, クログ ワイ, ウリカワ, ヘラオモダカ, ホタルイで高く, ノビ エ, マツバイ, コナギ, 一年生のカヤツリグ類で低 い。このことは, 現在普及している除草剤はマツバイを 除く多年生雑草には効果が不十分であるが，ノビエ， 、 ツバイ、コナギなどには効果が高いことを示しているも のと考える。

これら主要雑草の地域別の常在度をみると, 第 1 表お よび第 2 図に示すとおりで，ノビエ，マツバイは地域に 関倸なく, 全県的に同程度の常在度であったが, ホタル イは県中部から三陸沿岸にかけて常在度が高く, 北部抒 よび南部では中程度, 低湿地帯で低かった。クログワイ は, ホタルイと対照的に, 低湿地帯を含む県北部と南部 で高く, 中部で低かった。このことから, ホタルイの場 合, 乾田から半乾田に多く, クログワイは低湿がかった 地帯に多いといえるようである。ミズガヤツリは本県で もホタルイと並んで優占化の著しい雑草であるが, ミズ ガヤツリの常在度の高い地域は, 仙台湾沿岸南部を除く 県中南部であり, 内陸北部では中程度, 三陸沿岸北部と 北部低湿地帯で低かった。オモダカ類は県中北部から三 陸沿岸南部にかけての地帯と南部で高かった。ウリカワ は本県でも最近急に問題となってきた雑草であり, その 常在度は現在あまり高くないが, 仙台湾沿岸南部の低湿 地带および中北部の水田地帯を中心に中程度の常在度で あり, 温暖地と同様に今後急速に優占化することが考え られる。

\section{（2）植代後田植えまでの日数と除草法}

植代後田植えまでの日数は, 第 2 表に示したように, 経営規模, 土壤などにより当然異なるものと考えられる が, 主要水田地帯である県の中北部から三陸沿岸南部に
第 2 表 地域別の植代後田植えまでの日数と除草法

\begin{tabular}{|c|c|c|c|c|c|c|}
\hline までの日数 & \multicolumn{2}{|c|}{ 除草法 I 型 } & \multicolumn{2}{|c|}{ 除草法 II型 } & \multicolumn{2}{|c|}{ 除草法 III型 } \\
\hline 変異係数 & 実 施 & 十手取り & 実 施 & 十手取り & 実 施 & 十手取り \\
\hline 0.30 & $80 \%$ & $90 \%$ & $13^{\%}$ & ${ }^{\%}$ & $7^{\%}$ & $-\%$ \\
\hline 0.42 & 65 & 85 & 10 & 100 & 25 & 100 \\
\hline 0.51 & 83 & 50 & - & 一 & 17 & 100 \\
\hline 0.24 & 33 & 33 & 55 & 100 & 22 & 100 \\
\hline 0.39 & 61 & 50 & 8 & 100 & 31 & 50 \\
\hline 0.37 & 60 & 100 & 20 & 100 & 20 & 100 \\
\hline 0.49 & 36 & 86 & 33 & 50 & 31 & 83 \\
\hline 0.28 & 49 & 75 & 13 & 100 & 38 & 100 \\
\hline 0.47 & 27 & 67 & 37 & 75 & 36 & 75 \\
\hline 0.23 & 68 & 75 & - & - & 32 & 100 \\
\hline 0.35 & 85 & 100 & 15 & 100 & - & - \\
\hline 0.22 & 87 & 71 & 13 & 100 & - & - \\
\hline 0.46 & 50 & 50 & 50 & 100 & - & - \\
\hline 0.29 & 50 & 100 & 24 & 25 & 26 & - \\
\hline 0.45 & 57 & 74 & 20 & 60 & 23 & 77 \\
\hline
\end{tabular}

かけて長く, 県南部では短い傾向がみられた。このこと と地域別雑草発生状況との関倸は今後検討を要する点で あるが, 田植えまでの日数が長いほど移植後の雑草再生 が早いわけであり, 生育初期処理用除草剤の効果に大き く影響することも考えられるので, 除草㶡使用に際して は十分考虑する必要がある。

除草法については, 回答者のほとんどが除草剂を使用 しているが, その使用方法 (除草剤の組合せなど) が 35 例もあったので, 第 3 表のように 3 型に整理した。

第3 表 除草 法

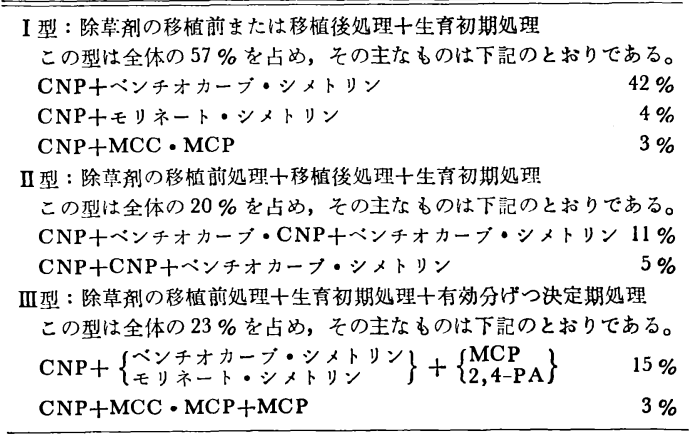

この 3 型と地域性との関係を第 2 表でみると, 県南部 では圧倒的に I 型が多く, 南部低湿地域では II 型が 55 \% とほぼ半分を占め, I 型と III型は同程度であった。中 北部の水田地帯では I 型が $50 \%$ を占め, II型が 30 35 \%で II 型が最も少なかった。北部内陸低湿地帯から三 陸沿岸にかけては南部々同様に I 型が多く, III型が極め て少ないのが特徴的である。

各除草法の除草効果を手取り（拾い草を含む）の要, 
不要から判断する（第 1 表参照）と，いずれもマツバイ を除く多年生雑草に対しては効果が不十分であり，I 型 で $74 \%$ ，II 型で $60 \%$ ，III 型では $77 \%$ (第 2 表参照) が手取りを行なっていた。

\section{（3）除草剤の処理時期（機械移植）}

調査の結果を県の標準除草法と比較すると, 第 3 図お よび第 4 図のようになり，I型の主体である $\mathrm{CNP}+$ べ ンチオカーブ・シメトリンは, 移植 2.8 日前十移植 17.5 日後の使用法と, 移植 2.7 日後十移植 18.7 日後の使用 法に分けられるが, CNP の移植後処理は, 前述の植代 かき後田植えまでの日数が長い場合は除草効果が低下す るおそれがある。また移植前処理についても, 移植 5 6 日前ころの処理の場合は, 生育初期処理除草剂の処理 時期を早めるなどの手段を講ずる必要があると考えられ る。

II型では， CNP+ベンチオカーブ・CNP+ベンチオ カーブ・シメトリンの場合, ペンチオカーブ・CNP が 10.7 日後処理, ベンチオカーブ・シメトリンが 25.3 日 後処理で，いずれも処理時期が遅すぎるといえる。ま た, CNP の 2 回処理は, 選択性からみて特定雑草が優 占化する可能性がある。

III型は，I 型に MCP または 2,4-PA の生育中期処 理を加えたものであり，I 型での問題点はそのまま残る と考えてよいよらである。

以上, 除草法および除草棛の処理洔期からみて, ホ夕 ルイなどの多年生雑草優占化の原因として, 一年生雑草 に有効な薬剤の普及, 機械移植栽培に伴う除草剤処理㭙
期の遅れ，中耕の減少などが挙げられる。現在，ホタル イなどの多年生雑草に極めて有効な除草剤の開発をみて いるが，除草剤の使用に際しては，散布すれば効くとい ら安易な考えをなくし，すでに普及されているものも含 め，その作用機構をよく理解し，その固場に発生する草 種を把握するとともに，固場条件や稲の生育などをよく 考慮して，除草剤の特性を十分に生かした使い方をする ことが大切である。

\section{摘要}

宮城県における, 主な水田雑草の地域別発生状況を中 心に，多年生雑草の優占化に関係女ると考えられた 2,3 の要因について調查した。

1）地域別の水田主要雑草の発生状況は，ホタルイな どの多年生雑草が多く，昭和 41 年調査による県内優占 雑草の順位と明らかに変わったといえる。また除草剤使 用後の残存の程度は, ホタルイを含む多年生雑草で高 く，マツバイおよび一年生雑草では低かった。

2) 除草法を，除草剤の組合せなどから 3 型に整理 し，除草効果をみたが，各地域とも，いずれの除草法も ホタルイなどの多年生雑草には効果が不十分の例が多 く, 手取りを行っていた。

3) 除草剂の処理時期は, 県の標準除草法に比し, 移 植後の処理, 生育初期処理ともに遅すぎるといえる。

4）調查結果から，最近の多年生雑草優占化の原因と して, 一年生雑草に有効な薬剂の普及, 除草剂処理時期 の遅れ，中耕の減少などが挙げられる。

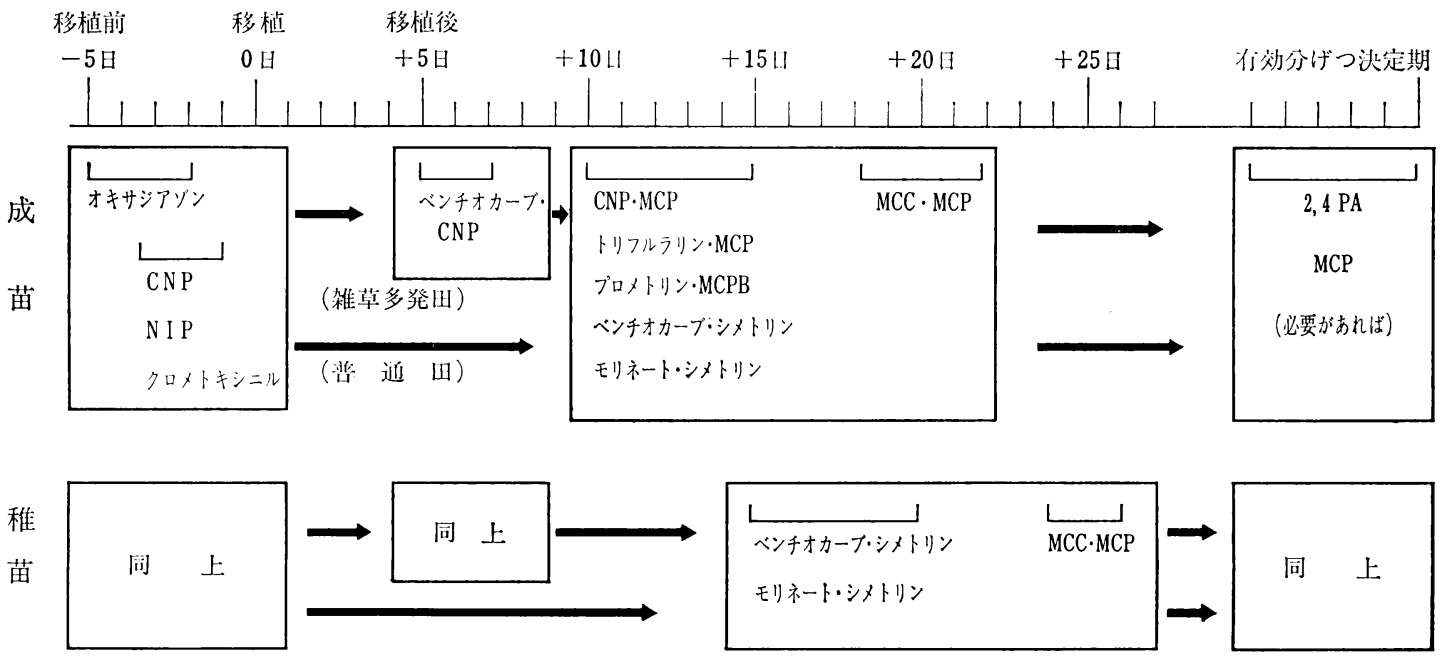

第3 図宮城県における標準除草法（農政部，1974） 

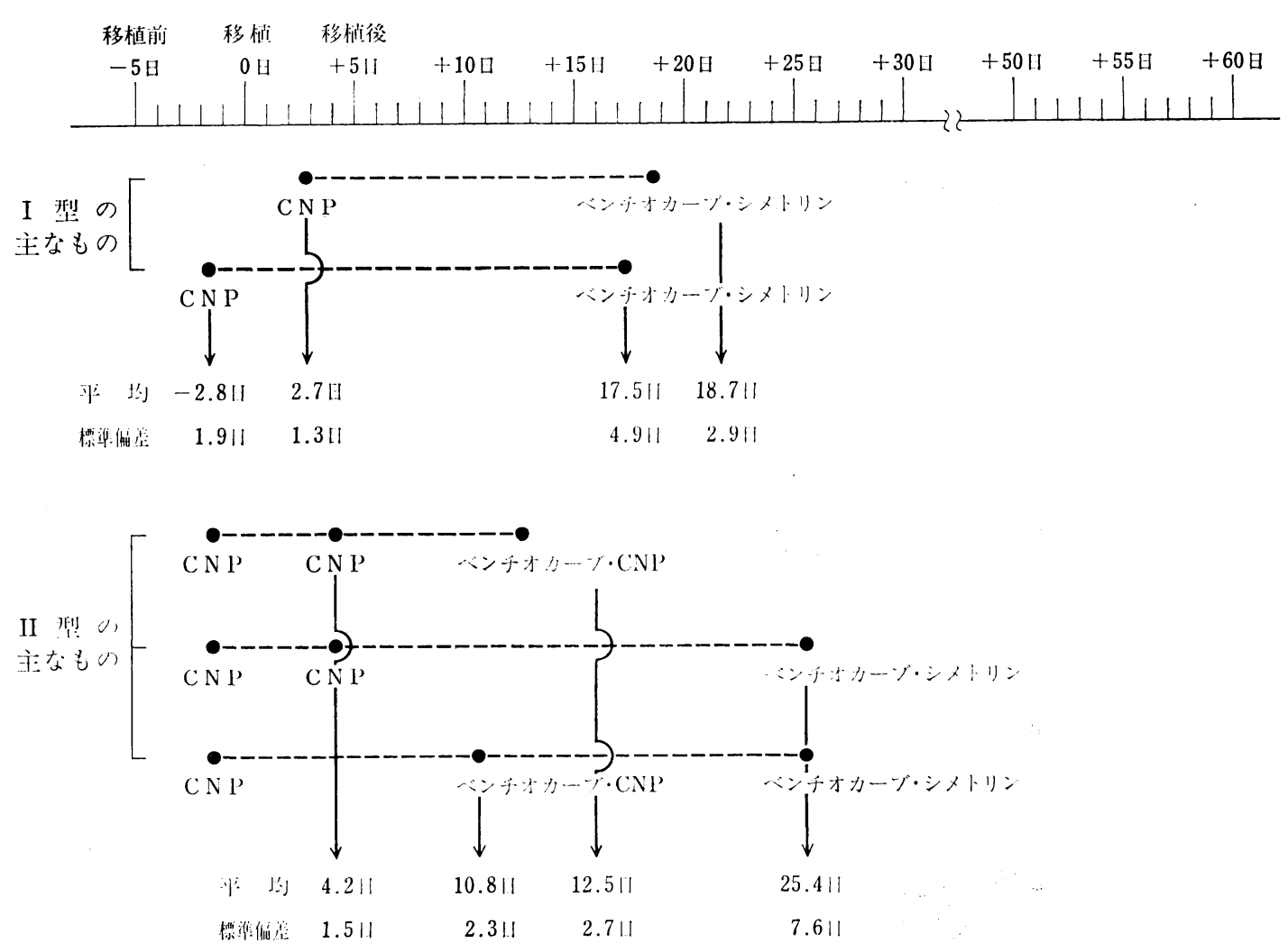

III

i:なもつ

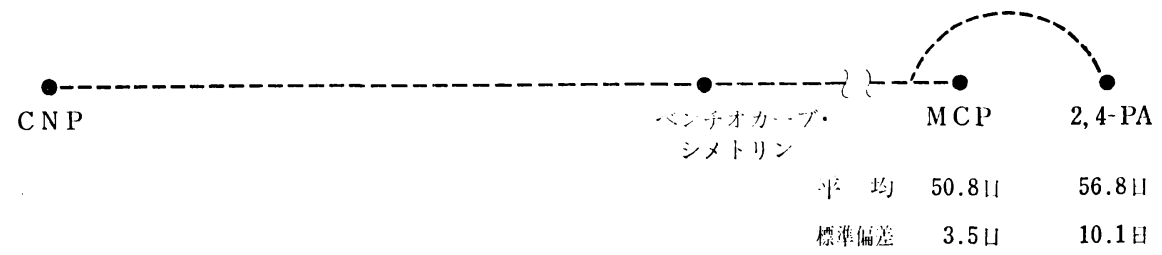

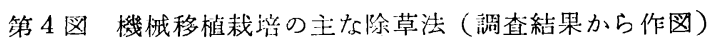

参 考 文 献

1）加藤治郎：農業百年技術史年表, 東北豊業技術史調查所 (1968),

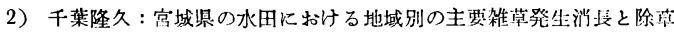
休系. 日植調東北支部会会報 6, (1969).

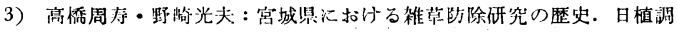
果北支部会会報 9, 10，(1973).

（1975 年 5 月 2 日受理）

\section{Distribution of Weeds on Paddy Field in Miyagi Prefecture}

Syuju TaKahashi*, Sozo Suzuki*, Shoshichi TAKeda*,

Tadatsugu KIKUсHI* and Kenji SATo**

* Furukawa Agriculture Experiment Station, Furukawa, Miyagi

** Kumiai Chemical Industry Co., Ltd., Otemachi, Tokyo

\section{Summary}

Distribution of main paddy weeds and the factors affecting heavy infestation of perennial weeds were 
investigated in each of the regions of Miyagi Prefecture in 1974.

1) Some perennial species, such as Scirpus juncoides, Cyperus serotinus, and Eleocharis kuroguwai infested large acreages in all regions. As these perennial weeds were not distributed widely in 1966, it seems clear that the marked changes have taken place in paddy weed community.

A number of perennial weeds including $S$. juncoides were found in most ricefields even after the use of herbicides, while only a few spikerush (Eleocharis acicularis) and annual weeds remained.

2) Methods of weed control practised by farmers were classed in three groups according to the ways of herbicide combination. In every region, perennials such as $S$. juncoides were not controlled sufficiently with any of these methods and most farmers needed to remove them by hands.

3) Time of herbicide application, in both weed pre-emergence and post-emergence, was generally too late and inadequate in comparison with the recommended application time.

4) As a result of the survey, it can be pointed out that the recent infestation of perennial weeds may be due to such factors as the wide use of herbicides effective only for annuals, the delay of herbicide application and the omission of intertillage.

\title{
熟畑化過程における雑草植生の变遷沉関する研究
}

\section{2. 雑草群落表示の基礎としての土壤酸度*}

\author{
新潟大学農学部附属農場 菅 原 清 康
}

\section{緒言}

著者は第 1 報において, 37 種類の雑草を適忍酸度の 強弱によって 6 段階に分類してこれに $0 \sim 5$ の序数を付 し,この一覧表を尺度として, 土袞の酸度を顧虑して雑 草群落を簡単な数であらわし, 地域的に適忍できる土壤 の指標とすることの可能性を指摘した。この場合, 上畩 酸度の測定については, どの深度から採土し, 一試料と してプロットの何カ所から採土したものを混合すればよ いのか，また一検体について何回測定すればもっとも適 正かつ合理的であるのかといったことが問題となるが，

これらの点については何らの検討も加えなかった。

一般に土壤の酸度は, 土壤の種類や層位, 土㙵水分や 腐植の多少, 開墾後年数や熟畑化の程度, 耕耘の方法や 投下資材の多少，あるい注同一畑地でも採土時期や測定 方法によって異なるのが通例である。さらに極端な場合 には，同一位置付近でも1日のうちで異なることもあ る。また一方, 雑草の根の分布は草種, 発生密度, 生育 段階, 土壤の肥痊, 土壤水分など種々の条件によって異 なる。このような西者の状態から, ある一定範囲の雑草
群落の生青土壌について, 理想的な形で土塆酸度をあら わ方方法としては, 雑草の根が分布している全層の土壤 を全生育期間を通じて詳細に测定し，これに基づく平均 土铱区応を求めることが最良と考えられる。しかしなが ら，このような方法では，ごく一部の群落について实験 的には実施することができるとしても，野外で同時に多 数の群落を測定するに当っては学力ならびに技術の点か らまず不可能に近い。したがって, 雑草群落について土 塆酸度の調査を実施するに当っては, 簡易かつ適正であ るとともに，畑地の実態に適合した採土方法の探索が必 要である。

第 1 報で示した土壤酸度は, 慣例にしたがって地下 5 $\mathrm{cm}$ の深度から 1 プロット任意に 10 力所採土し，これを 混合した一検体について 5 回測定した平均值を求める方 法により 15 力年継続したもので，この間に拉いて著者 自らその根拠について検討を加えることがなかった。今 後, 第 1 報の成果を基礎として, 土壇の酸度を顧慮しつ つ雑草を群落の形で，これを簡羝な数であらわし，熟畑 化の程度や土壌の指標とする方问に発展させようとする ならば，少なくとも第 1 報で突施してきた方法の妥当性

* 第 13 回講演会（昭和 49 年 4 月）に扣いて発表 